\title{
Integrated Management of Early Blight of Tomato (Lycopersicon esculentum Mill.) caused by Alternaria solani (Ellis and Martin) Jones and Grout
}

\author{
Salimso Chapei, Narola Pongener* and Valenta Kangjam
}

Department of Plant Pathology, School of Agricultural Sciences and Rural Development, Nagaland University, Medziphema Campus-797 106, Nagaland, India

*Corresponding author

\section{Keywords}

Alternaria solani, Bio-control agents, Plant extract, Fungicide and integrated disease management

Article Info

Accepted:

18 April 2019

Available Online:

10 May 2019

\section{A B S T R A C T}

The present study was carried out to find the integrated management of early blight of tomato (Lycopersicon esculentum Mill.) caused by Alternaria solani. Tomato (Lycopersicon esculentum Mill.) is an important vegetable crop which is grown all over the world. Early blight of tomato, caused by Alternaria solani is one of the most important diseases in tomato. Two fungicides i.e. Mancozeb $75 \mathrm{WP}$ and Hexaconazole $5 \mathrm{EC}$ at different concentrations $(0.1 \%, 0.2 \%$ and $0.3 \%)$, two bio-agents viz., Trichoderma harzianum and T. koningii and two botanicals i.e. garlic bulb extract and neem leaves extract at different concentrations $(5 \%, 10 \%$ and $15 \%)$ were evaluated in vitro against $A$. solani. On the basis of in vitro tests, both the fungicides caused significant inhibition of the mycelial growth. The highest inhibition of mycelial growth was recorded in all concentrations of Hexaconazole @ 0.1\%, 0.2\% and 0.3\% with per cent inhibition of 94.44 followed by Mancozeb @ $0.2 \%$ with 93.33 per cent inhibition. In vitro screening of botanicals revealed that the per cent inhibition of mycelial growth was recorded most effective with 5\% garlic bulb extract $(84.81 \%)$ followed by garlic @ 10\% $(79.63 \%)$ and the least mycelial inhibition was exhibited by neem leaves extract@15\% with $82.26 \%$. Among the bioagents $T$. harzianum and T. koningii completely covered the mycelial growth of the test pathogen in 5 days and thus was highly antagonistic in nature and significantly reduced the growth of the pathogen. Under IDM, least mean value of disease severity was recorded from $\mathrm{IDM}_{2}$ (soil application of $T$. harzianum + seedling dip with garlic extract + foliar spray with Hexaconazole @ 0.1\%) with 1.98 per cent. This was followed by $\mathrm{IDM}_{3}$ (burning with crop debris + seedling dip with Hexaconazole + foliar spray with garlic extract). Highest mean disease intensity of 23.04 per cent was recorded from $\mathrm{IDM}_{0}$ (control). Maximum growth and yield was recorded from $\mathrm{IDM}_{2}$ with $207.15 \mathrm{q} / \mathrm{h}$ with cost benefit ratio of 4.40 .

\section{Introduction}

Tomato (Lycopersicon esculentum Mill.) is one of the distinguished vegetable under
Solanaceae family. It is one of the most popular vegetable crops grown all over the world. China leads in production and productivity of tomato followed by India, 
United State of America, Turkey, Egypt and Iran. The total tomato cultivation area in India is 879.6 hectare and production is 18226.6 metric tons with the productivity of 20.7 metric tons per hectare. There has been a gradual increase in area under tomato while the production has been fluctuating due to various diseases and insect pest damage. There are several diseases on tomato caused by fungi, bacteria, viruses, nematodes and abiotic factors (Balanchard, 1992; Gomaa, 2001 and Abdel-Sayed, 2006). It is estimated that fungal diseases of tomato are responsible for $30 \%$ increase in production costs on fungicides used to combat these diseases (Grigolli et al., 2011). Among the diseases, early blight, caused by Alternaria solani (Ellis and Martin) Jones and Grout, is one of the most important and frequent disease of the crop worldwide (Song et al., 2011).

Alternaria blight is one the most important disease along with damping off, bacterial blight and tomato leaf curl virus (TLCV) in Varanasi with an average intensity varying from $35-40 \%$ every year. Losses may go up $80-86 \%$ when prolonged suitable weather condition prevails for early blight (Pandey and Pandey 2007). Early blight symptom appears as brown leaf spots marked with concentric rings to give a target effect. These spots enlarge slowly and may eventually destroy the leaves. With this in view, the present investigation has therefore been undertaken to study the usefulness of bio agents, botanicals, chemicals and cultural practices in the integrated management of early blight of tomato caused by Alternaria solani.

\section{Materials and Methods}

The infected leaf sample of tomato were collected from Central Institute of Horticulture Medziphema, Nagaland and the pathogen Alternaria solani was isolated from the naturally infected tomato plants showing typical symptoms of the disease. The infected portions of the leaves along with some healthy tissue were cut into small pieces. These pieces were surface sterilized with 0.1 per cent mercuric chloride solution for 30 seconds then washed thoroughly in sterile distilled water thrice to remove traces of mercuric chloride, if any, and then transferred aseptically to sterilized potato dextrose agar (PDA) plates.

They were incubated at $27 \pm 1^{\circ} \mathrm{C}$ and checked after every 24 hour for the growth of the fungus. The fungus was identified based on the morphological characteristics. Later, a bit of the fungal growth was transferred to PDA plates. The pure culture of the fungus was obtained by following hyphal tip culture under aseptic conditions (Rangaswamy, 1972).

The antagonists used in the present investigation, viz., Trichoderma harzianum and $T$. koningii were procured from the Biocontrol Laboratory, Department of Agriculture Medziphema, Nagaland. The selected botanicals neem leaves and garlic bulb were collected from Medziphema, Nagaland.

\section{Preparation of plant extracts}

Aqueous extracts of two plants were evaluated against Alternaria solani. Fresh leaves of neem and garlic bulb were collected and washed properly with distilled water. Hundred grams of fresh and washed plant materials (leaves, bulb) were ground well in a pestle and mortar with $100 \mathrm{ml}(1: 1 \mathrm{w} / \mathrm{v})$ sterilized distilled water. The macerate was filtered through muslin cloth and the extract thus obtained was considered as standard extract (100 \%) (Shekhawat and Prasada, 1971). 
In vitro evaluation of fungicides on radial growth of pathogen

Mancozeb and Hexaconazole were tested at $0.1,0.2$ and 0.3 per cent concentrations for their efficacy on the mycelial growth of Alternaria solani by poison food technique (Nene and Thapliyal, 1982), to select the most promising chemicals for further evaluation under field conditions.

Required amount of chemicals were measured out and mixed in $100 \mathrm{ml}$ molten PDA medium and $20 \mathrm{ml}$ of poisoned media was poured into each of the sterilized petriplates $(90 \mathrm{~mm})$ under aseptic conditions. The fungal disc of the pathogen $(5 \mathrm{~mm})$ of 7 days old culture was cut out through the flame sterilized cork borer and transferred in the center of petriplates. Plates were incubated at $27 \pm 1^{\circ} \mathrm{C}$. The observations were recorded after every 24 hours.

\section{Effect of botanicals on radial growth of pathogen}

The plant extract were screened under in vitro condition against Alternaria solani following poison food technique as suggested by Nene and Thapliyal, 1982, to select the most promising plants extract and for further evaluation under field conditions. Required volume of plants extract was measured out and mixed in sterilized molten PDA medium.

The medium was shaken thoroughly for the uniform mixing of the plant extracts. Twenty $\mathrm{ml}$ of poisoned media was poured into each of sterilized petriplates $(90 \mathrm{~mm})$ under aseptic conditions. Then $5 \mathrm{~mm}$ disc of 7 days old culture of the pathogen was cut out through flame sterilized cork borer and transferred in the center of petriplates. Plates were incubated at $27 \pm 1^{\circ} \mathrm{C}$ for 7 days. The observation was recorded after every 24 hours.

\section{Effect of biocontrol agent on radial growth of pathogen}

Biocontrol agents viz., Trichoderma harzianum and Trichoderma koningii were screened under in vitro condition against Alternaria solani following dual culture technique as suggested by Dennis and Webster, 1971, to select the most promising bio-control agent and further evaluation under field conditions for its antagonistic effect. Culture disc of $5 \mathrm{~mm}$ diameter each of the fungal antagonists and the pathogen were cut with the help of a sterilized cork borer from the margin of the actively growing culture and transferred to PDA in petriplates $(90 \mathrm{~mm}$ diameter) on opposite sides approximately at $10 \mathrm{~mm}$ from the periphery of the plate. A control having the test pathogen only was also kept for comparison. The petriplates were then incubated at $27 \pm 1^{\circ} \mathrm{C}$ till the control plates were comparatively covered fully by the pathogen.

The experiment was conducted in completely randomized block design (CRBD) with three replications in each treatment. Per cent inhibition of mycelial growth calculated using the following formula (Vincent, 1927).

$\mathrm{I}=\frac{\mathrm{C}-\mathrm{T}}{\mathrm{T}}$

Where, I= Per cent inhibition of mycelial growth

$\mathrm{C}=$ Colony diameter in control $(\mathrm{mm})$

$\mathrm{T}=$ Colony diameter treatment $(\mathrm{mm})$

\section{In vivo evaluation}

Based on the above in vitro test the best promising fungicide, botanical and bio agent were selected. The experiment was laid out in Randomized Block Design (RBD) with three replications. The treatment combinations were as follows. 
$\mathrm{IDM}_{0}=$ Control

$\mathrm{IDM}_{1}=$ Mulching + seedling $\operatorname{dip}(T$. harzianum) +foliar spray (garlic bulb extract)

$\mathrm{IDM}_{2}=$ Soil application ( $T$. harzianum) + seedling dip (garlic bulb extract) + foliar spray (Hexaconazole)

$\mathrm{IDM}_{3}=$ Burning with plant debris + seedling dip (Hexaconazole) + foliar spray (garlic bulb extract)

For recording of disease severity five plants were selected randomly from each plot at 15 days interval starting from the first appearance of the disease using a 0-9 scale (Mayee and Datar, 1986) which are rated as follows:

0: $\quad$ No infection

1: $\quad 1-10 \%$ leaves infected

3: $\quad 11-25 \%$ leaves infected

5: $\quad 26-50 \%$ leaves infected

7: $\quad 51-75 \%$ leaves infected

9: $\quad$ Above $75 \%$ leaves infected

Disease intensity was calculated with the above scales using the formula given by Davis et al., (1993).

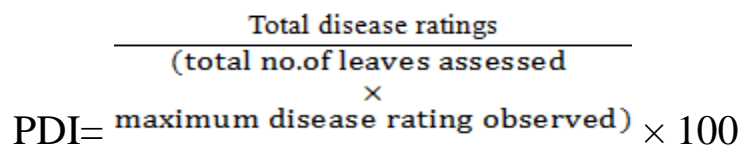

\section{Results and Discussion}

Two selected fungicides viz., Mancozeb and Hexaconazole at different concentrations @ $0.1 \%, 0.2 \%$ and $0.3 \%$, two botanicals extract viz., neem leaves and garlic bulb extract at $5 \%, 10 \%$ and $15 \%$ concentrations were evaluated using poison food technique.

Two bio- agents viz., Trichoderma harzianum and Trichoderma koningii were tested against the pathogen by dual culture technique. The average growth of pathogen was recorded at every 24 hours intervals. In vitro evaluation revealed that all the plant extract at different concentration were significantly effective in inhibiting the mycelial growth of Alternaria solani. However, the per cent inhibition of mycelial growth was recorded most effective with 5\% garlic bulb extract $(84.81 \%)$. This was followed by garlic@10\% with 79.63 per cent inhibition statistically at par with garlic @ 15\% (78.52 \%). The least mycelial inhibition was exhibited by neem leaves extract@15\% with 64.81\%.

It was also observed that the test botanicals decreased the inhibition of mycelial growth with increase in their concentration. The results are in conformity with Chethana et al., (2012) where extract of garlic (20\%) was found to be most effective in causing 100 per cent inhibition of mycelial growth of $A$. solani. Narendrappa and Nandini (2013) also reported that the bio agent Trichoderma harzianum, bulb extract of Allium sativum and fungicide Avtar were the best in inhibiting the mycelial growth of Alternaria solani.

Among the botanicals tested, garlic bulb extract exhibited maximum per cent inhibition which may be due to presence of volatile oil which contains diallyl-disulphide, diallyl-trisulphide and sulphodoxides derived from allium.

The presence of antibiotic constituent in the form of phenolic, resinous, gummy and nonvolatile substances of unknown nature in different botanicals which contribute to the inhibitory activity of the plant extracts has been reported by Skinner, 1955, Amonkar and Banerji, 1971 and Anonymous, 1972.

Two bioagents viz., Trichoderma harzianum and Trichoderma koningii were evaluated against the pathogen under in vitro condition (Table 1-4). 
Table.1 In vitro evaluation of fungicides, botanicals and bio agents against mycelial growth of Alternaria solani

\begin{tabular}{|c|c|c|c|c|c|c|c|c|c|c|c|c|}
\hline & & 24 hours & & 48 hours & & 72 hours & & 96 hours & & 120 hours & & \\
\hline & & $\begin{array}{l}\text { Mean } \\
\text { radial } \\
\text { growth } \\
(\mathbf{m m})\end{array}$ & PI & $\begin{array}{l}\text { Mean } \\
\text { radial } \\
\text { growth } \\
(\mathbf{m m})\end{array}$ & PI & $\begin{array}{l}\text { Mean } \\
\text { radial } \\
\text { growth } \\
(\mathbf{m m})\end{array}$ & PI & $\begin{array}{l}\text { Mean radial } \\
\text { growth } \\
(\mathrm{mm})\end{array}$ & PI & $\begin{array}{l}\text { Mean radial } \\
\text { growth }(\mathbf{m m})\end{array}$ & PI & Mean \\
\hline $\mathbf{T}_{0}=$ Control & & 16.33 & 0.00 & 32.33 & 0.00 & 43.33 & 0.00 & 58.67 & 0.00 & 90.00 & 0.00 & 0.00 \\
\hline $\mathbf{T}_{1}=$ Mancozeb & $0.1 \%$ & 0.00 & $\begin{array}{l}100.00 \\
(90.00)\end{array}$ & 0.00 & $\begin{array}{l}100.00 \\
(90.00)\end{array}$ & 0.00 & $\begin{array}{l}100.00 \\
(90.00)\end{array}$ & 6.00 & $\begin{array}{c}89.77 \\
(71.35)\end{array}$ & 7.67 & $\begin{array}{c}91.45 \\
(73.04)\end{array}$ & $\begin{array}{l}96.24 \\
(78.82)\end{array}$ \\
\hline$T_{2}=$ Mancozeb & $0.2 \%$ & 0.00 & $\begin{array}{l}100.00 \\
(90.00)\end{array}$ & 0.00 & $\begin{array}{l}100.00 \\
(90.00)\end{array}$ & 0.00 & $\begin{array}{l}100.00 \\
(90.00)\end{array}$ & 5.33 & $\begin{array}{c}90.89 \\
(72.46)\end{array}$ & 6.00 & $\begin{array}{c}93.33 \\
(75.07)\end{array}$ & $\begin{array}{c}96.84 \\
(79.76)\end{array}$ \\
\hline $\mathbf{T}_{3}=$ Mancozeb & $0.3 \%$ & 0.00 & $\begin{array}{l}100.00 \\
(90.00)\end{array}$ & 0.00 & $\begin{array}{l}100.00 \\
(90.00)\end{array}$ & 0.00 & $\begin{array}{l}100.00 \\
(90.00)\end{array}$ & 6.33 & $\begin{array}{l}89.18 \\
(70.82\end{array}$ & 8.67 & $\begin{array}{c}90.37 \\
(71.39)\end{array}$ & $\begin{array}{c}95.91 \\
(78.33)\end{array}$ \\
\hline $\begin{array}{c}\mathbf{T}_{4}=\text { Hexaconazo } \\
\text { le }\end{array}$ & $0.1 \%$ & 0.00 & $\begin{array}{l}100.00 \\
(90.00)\end{array}$ & 0.00 & $\begin{array}{l}100.00 \\
(90.00)\end{array}$ & 0.00 & $\begin{array}{l}100.00 \\
(90.00)\end{array}$ & 5.00 & $\begin{array}{c}91.47 \\
(73.02)\end{array}$ & 5.00 & $\begin{array}{c}94.44 \\
(76.37)\end{array}$ & $\begin{array}{c}97.18 \\
(80.33)\end{array}$ \\
\hline $\begin{array}{c}\mathrm{T}_{5}=\text { Hexaconazo } \\
\text { le }\end{array}$ & $0.2 \%$ & 0.00 & $\begin{array}{l}100.00 \\
(90.00)\end{array}$ & 0.00 & $\begin{array}{l}100.00 \\
(90.00)\end{array}$ & 0.00 & $\begin{array}{l}100.00 \\
(90.00)\end{array}$ & 5.00 & $\begin{array}{c}91.47 \\
(73.02)\end{array}$ & 5.00 & $\begin{array}{l}94.44 \\
(76.37)\end{array}$ & $\begin{array}{c}97.18 \\
(80.33)\end{array}$ \\
\hline $\mathrm{T}_{7}=$ Neem & $5 \%$ & 9.33 & $\begin{array}{c}43.10 \\
(41.03)\end{array}$ & 11.33 & $\begin{array}{c}64.67 \\
(53.56)\end{array}$ & 14.00 & $\begin{array}{c}67.58 \\
(55.31)\end{array}$ & 19.33 & $\begin{array}{c}67.03 \\
(54.96)\end{array}$ & 23.67 & $\begin{array}{c}73.70 \\
(59.15)\end{array}$ & $\begin{array}{c}63.21 \\
(52.66)\end{array}$ \\
\hline $\mathrm{T}_{8}=$ Neem & $10 \%$ & 9.00 & $\begin{array}{c}44.72 \\
(41.95)\end{array}$ & 12.67 & $\begin{array}{c}60.40 \\
(51.04)\end{array}$ & 15.33 & $\begin{array}{c}64.41 \\
(53.41)\end{array}$ & 23.00 & $\begin{array}{c}60.76 \\
(51.23)\end{array}$ & 28.33 & $\begin{array}{l}68.52 \\
(55.87)\end{array}$ & $\begin{array}{l}59.76 \\
(50.63)\end{array}$ \\
\hline$T_{9}=$ Neem & $15 \%$ & 12.00 & $\begin{array}{c}26 . .48 \\
(30.97)\end{array}$ & 14.00 & $\begin{array}{l}56.25 \\
(48.61)\end{array}$ & 19.00 & $\begin{array}{c}56.02 \\
(48.46)\end{array}$ & 25.67 & $\begin{array}{c}56.21 \\
(48.57)\end{array}$ & 31.67 & $\begin{array}{c}64.81 \\
(53.62)\end{array}$ & $\begin{array}{c}51.95 \\
(46.12)\end{array}$ \\
\hline $\mathbf{T}_{10}=$ Garlic & $5 \%$ & 0.00 & $\begin{array}{l}100.00 \\
(90.00)\end{array}$ & 6.00 & $\begin{array}{c}81.30 \\
(64.40)\end{array}$ & 6.33 & $\begin{array}{c}85.35 \\
(67.51)\end{array}$ & 10.33 & $\begin{array}{c}82.33 \\
(65.20)\end{array}$ & 13.67 & $\begin{array}{c}84.81 \\
(67.08)\end{array}$ & $\begin{array}{c}86.75 \\
(68.65)\end{array}$ \\
\hline $\mathrm{T}_{11}=$ Garlic & $10 \%$ & 0.00 & $\begin{array}{l}100.00 \\
(90.00)\end{array}$ & 5.33 & $\begin{array}{c}83.27 \\
(65.93)\end{array}$ & 7.33 & $\begin{array}{c}83.03 \\
(65.69)\end{array}$ & 10.33 & $\begin{array}{c}82.35 \\
(65.24)\end{array}$ & 18.33 & $\begin{array}{c}79.63 \\
(63.18)\end{array}$ & $\begin{array}{c}85.65 \\
(67.74)\end{array}$ \\
\hline T 1 $12=$ Garlic & $15 \%$ & 0.00 & $\begin{array}{l}100.00 \\
(90.00)\end{array}$ & 6.33 & $\begin{array}{c}80.15 \\
(63.51)\end{array}$ & 9.67 & $\begin{array}{c}77.65 \\
(61.80)\end{array}$ & 14.67 & $\begin{array}{c}75.00 \\
(60.01)\end{array}$ & 19.33 & $\begin{array}{c}78.52 \\
(62.40)\end{array}$ & $\begin{array}{c}82.26 \\
(65.09)\end{array}$ \\
\hline S. Em \pm & & & 0.43 & & 1.13 & & 0.83 & & 0.84 & & 0.43 & \\
\hline
\end{tabular}

Note: Figures in the table are mean values and those in parenthesis are angular transformed value 
Table.2 In vitro evaluation of bio agents against Alternaria solani

\begin{tabular}{|c|c|c|c|c|c|c|c|c|c|c|c|}
\hline \multirow[t]{3}{*}{ Treatment } & \multicolumn{9}{|c|}{ Inhibition percentage } & & \multirow[b]{2}{*}{ Mean } \\
\hline & 24 hours & & 48 hours & & 72 hours & & 96 hours & & 120 hours & & \\
\hline & $\begin{array}{c}\text { Mean } \\
\text { radial } \\
\text { growth } \\
(\mathbf{m m})\end{array}$ & PI & $\begin{array}{l}\text { Mean radial } \\
\text { growth }(\mathrm{mm})\end{array}$ & PI & $\begin{array}{l}\text { Mean radial } \\
\text { growth } \\
(\mathrm{mm})\end{array}$ & PI & $\begin{array}{l}\text { Mean radial } \\
\text { growth }(\mathrm{mm})\end{array}$ & PI & $\begin{array}{l}\text { Mean radial } \\
\text { growth }(\mathbf{m m})\end{array}$ & PI & \\
\hline $\begin{array}{c}\mathbf{T}_{1}=\text { Trichoderma } \\
\text { harzianum }\end{array}$ & 10.00 & 38.80 & 19.33 & 39.63 & 32.33 & 25.06 & 39.00 & 33.80 & 41.67 & 53.70 & 38.20 \\
\hline $\begin{array}{c}\mathrm{T}_{2}=\text { Trichoderma } \\
\text { koningii }\end{array}$ & 9.00 & 44.95 & 21.67 & 32.58 & 34.33 & 20.44 & 41.33 & 29.48 & 43.67 & 51.48 & 35.79 \\
\hline t Stat & & -19 & & 3.86 & 30.11 & & 3.47 & & 3.46 & & \\
\hline t Critical two-tail & & 4.30 & & 4.30 & 4.30 & & 4.30 & & 4.30 & & \\
\hline
\end{tabular}

Table.3 Effect of integrated disease management on plant growth

\begin{tabular}{|c|c|c|c|c|c|c|c|c|c|c|c|c|}
\hline \multirow[t]{3}{*}{ Treatment } & \multicolumn{3}{|c|}{ Plant height (cm) } & & \multicolumn{3}{|c|}{ Stem girth (cm) } & & \multicolumn{3}{|c|}{ Number of branches } & \multirow[b]{3}{*}{ Mean } \\
\hline & & Time & & & & Time & & & & Time & & \\
\hline & 30DAT & 60DAT & 90DAT & Mean & 30DAT & 60DAT & 90DAT & Mean & 30DAT & 60DAT & 90DAT & \\
\hline $\mathrm{IDM}_{0}$ & 14.47 & 36.67 & 37.33 & 29.49 & 1.44 & 1.96 & 2.45 & 1.95 & 2.87 & 4.27 & 6.43 & 4.52 \\
\hline IDM $_{1}$ & 15.60 & 42.20 & 43.53 & 33.77 & 1.48 & 2.23 & 2.53 & 2.08 & 3.33 & 5.67 & 6.33 & 5.11 \\
\hline IDM $_{2}$ & 17.40 & 49.60 & 50.93 & 39.31 & 1.81 & 3.05 & 3.20 & 2.68 & 5.00 & 7.67 & 8.33 & 7.00 \\
\hline $\mathrm{IDM}_{3}$ & 16.80 & 46.73 & 47.60 & 37.04 & 1.69 & 2.24 & 2.65 & 2.19 & 3.67 & 6.00 & 7.00 & 5.55 \\
\hline Mean & 16.06 & 43.80 & 44.84 & & 1.60 & 2.37 & 2.70 & & 3.71 & 5.90 & 7.02 & \\
\hline
\end{tabular}

*Mean of three replication

$\mathrm{SEm} \pm 0.85 \quad \mathrm{CD}(\mathrm{p}=0.05)$ to compare treatment means over time $=2.96$ for plant height

$\mathrm{SEm} \pm 0.49 \quad \mathrm{CD}(\mathrm{p}=0.05)$ to compare time means over treatment $=1.20$ for plant height

$\mathrm{SEm} \pm 0.80 \mathrm{CD}(\mathrm{p}=0.05)$ to compare interaction of treatment $\mathrm{x}$ time $=2.41$ for plant height

$\mathrm{SEm} \pm 0.09 \quad \mathrm{CD}(\mathrm{p}=0.05)$ to compare treatment means over time $=0.33$ for stem girth

$\mathrm{SEm} \pm 0.07 \mathrm{CD}(\mathrm{p}=0.05)$ to compare time means over treatment $=0.21$ for stem girth

$\mathrm{SEm}+0.14 \mathrm{CD}(\mathrm{p}=0.05)$ to compare interaction of treatment $\mathrm{x}$ time $=0.43$ for stem girth

$\mathrm{SEm} \pm 0.20 \quad \mathrm{CD}(\mathrm{p}=0.05)$ to compare treatment means over time $=0.71$ for number of branches

$\mathrm{SEm} \pm 0.18 \mathrm{CD}(\mathrm{p}=0.05)$ to compare time means over treatment $=0.55$ for number of branches

$\mathrm{SEm} \pm 0.37 \mathrm{CD}(\mathrm{p}=0.05)$ to compare interaction of treatment $\mathrm{x}$ time $=1.1$ for number of branches 
Table.4 Effect of integrated disease management on yield

\begin{tabular}{|c|c|c|c|c|}
\hline \multirow{2}{*}{ Treatment } & \multicolumn{3}{|c|}{ Yield } & \\
\cline { 2 - 5 } & Number of fruit/plant & $\begin{array}{c}\text { Weight of } \\
\text { fruit/plant (gram) }\end{array}$ & $\begin{array}{c}\text { Weight of } \\
\text { fruit/plot (gram) }\end{array}$ & Yield (q/ha) \\
\hline IDM $_{\mathbf{0}}$ & 13.20 & 256.67 & 2860.67 & 71.30 \\
\hline $\mathbf{I D M}_{\mathbf{1}}$ & 16.10 & 390.00 & 6790.00 & 169.7 \\
\hline $\mathbf{I D M}_{\mathbf{2}}$ & 35.80 & 583.33 & 8286.67 & 207.15 \\
\hline $\mathbf{I D M}_{\mathbf{3}}$ & 20.13 & 460.00 & 7700.00 & 192.5 \\
\hline $\mathbf{S E m} \pm$ & 1.10 & 2.22 & 547.51 & \\
\hline $\mathbf{C D}(\mathbf{p = 0 . 0 5})$ & 3.82 & 6.65 & 1894.64 & \\
\hline
\end{tabular}

Table.5 Effect of integrated treatment on disease severity (per cent disease index)

\begin{tabular}{|c|c|c|c|c|}
\hline \multirow{2}{*}{ Treatment } & \multicolumn{3}{|c|}{ Time } & Mean \\
\cline { 2 - 5 } & 45DAT & 60DAT & 75DAT & 23.04 \\
\hline IDM $_{\mathbf{0}}$ & $5.69(13.80)$ & $21.1(27.34)$ & $42.33(40.58)$ & $\mathbf{7 . 4 3}$ \\
\hline IDM $_{\mathbf{1}}$ & $2.83(9.68)$ & $7.92(16.34)$ & $11.54(19.85)$ & $\mathbf{1 . 9 8}$ \\
\hline IDM $_{\mathbf{2}}$ & $0.88(5.38)$ & $1.84(7.79)$ & $3.23(10.35)$ & $\mathbf{5 . 7 0}$ \\
\hline IDM $_{\mathbf{3}}$ & $1.45(6.91)$ & $5.89(14.04)$ & $9.78(18.22)$ & $\mathbf{1 6 . 7 2}$ \\
\hline Mean & $\mathbf{2 . 7 1}$ & $\mathbf{9 . 1 8}$ & $\mathbf{1 8}$ \\
\hline
\end{tabular}

* Mean of three replication

$\mathrm{SEm} \pm 0.96 \mathrm{CD}(\mathrm{p}=0.05)$ to compare treatment means over time $=3.35$

$\mathrm{SEm} \pm 0.45 \quad \mathrm{CD}(\mathrm{p}=0.05)$ to compare time means over treatment $=1.36$

$\mathrm{SEm} \pm 0.91 \mathrm{CD}(\mathrm{p}=0.05)$ to compare interaction of treatment $\mathrm{x}$ time $=2.73$

The results of the experiment were subjected to paired-t test at $5 \%$ level of significance, which revealed that effect of $T$. harzianum bio agents was significantly better than $T$. koningii in reducing the growth of the pathogen. Shuakkat and Rao (2013) also reported that culture filtrate of all the five Trichoderma species (viz., T. viride, T. virens, T. harzianum, T. koningii and T. pseudo koningii) retarded the growth of $A$. solani but $T$. viride and $T$. harzianum more strongly suppressed the growth of Alternaria solani. The inhibition of Alternaria solani in the presence of Trichoderma spp could be due to antibiosis or hyperparasitism. Both $T$. harzianum and $T$ koningii overgrew on the pathogen colony and complete invasion and sporulation occurred after five days.

\section{Effect of integrated disease management on} disease severity of early blight of tomato

Under IDM there were three treatments where different individual methods were integrated together and applied for the experiment viz., $\mathrm{IDM}_{1}$ (mulching with polyethylene sheet + seedling dip with Hexaconazole + foliar spray with garlic extract), IDM $_{2}$ (soil application of T. harzianum + seedling dip with garlic extract + foliar spray with Hexaconazole) and $\mathrm{IDM}_{3}$ (burning with crop debris + seedling dip with Hexaconazole + foliar spray with garlic extract) depicts the disease severity with respect to integrated disease management and dates of observation $(45,60$ and 75 DAT) against the early blight of tomato (Table 5). 
The experimental data were subjected to measurement over time analysis, and it showed that effect of three IDMs on disease severity of early blight of tomato were significant. The effect of time as well as interaction effect of IDMs and time was found significant at 5\% level of significance. Minimum disease intensity was recorded from $\mathrm{IDM}_{2}$ with $1.98 \%$. This was followed by $\mathrm{IDM}_{3}(5.70 \%)$ which was statistically at par with $\mathrm{IDM}_{1}$.

There were also significant variations on disease intensity at different time of observation over treatments. The highest mean value of 16.72 was recorded at 75 days after transplanting. The interaction between the treatments and time of observation revealed significant variations where $\mathrm{IDM}_{2}$ gave the lowest disease intensity of 1.98 per cent and the highest was recorded from IDM $_{0}$ with 42.33 per cent.

All the treatments were significantly superior over control in reducing the disease severity. Integrated management of early blight of tomato not only checked the disease severity but also increased the yield of tomato fruits. The better performance of the integrated methods over control may be due to the combined action of the fungicide, botanical, bio agent and cultural practices. The present findings are in conformity with the observations recorded by Rashmi and Vishunavat (2012) who was of the view that cultural practices when it is integrated with fungicides reduced the per cent disease index and increased the yield.

\section{References}

Abdel-Sayed, M H F., 2006. Pathological, Physiological and Molecular variations among isolates of Alternaria solani the causal of tomato early blight disease Ph.D. Thesis fac.agric. Cairo University.

Amonkar, SV., and Banerji A., 1971. Antifungal activity of certain plant extracts against Macrophomina phaseolina. Science 74: 1343-1344.

Anonymous. 1972. The wealth of India. Council of Scientific and Industrial Research (CSIR), New Delhi, India. pp. 237.

Balanchard, D., 1992. A colour atlas of tomato disease. Wolfe Publication Limited, Book House, London. pp. 298.

Chethana, B S., Ganeshan G, Rao S A and Bellishree K. 2012. In vitro evaluation of plant extracts, bioagents and fungicides against Alternaria porri (ellis) cif. causing purple blotch disease of onion. Pest Management in Horticultural Ecosystems 18 (2): 194198.

Dennis, C., and Webster J. 1971. Antagonistic properties of species groups of Trichoderma III. Production of volatile antibiotics. Transactions of British Mycological Society 51: 363369.

Gomaa A M. 2001. Pathological studies on early blight of tomato M.sc. Thesis fac Agric., Cairo University.

Grigolli, J F J., Kubota M M, Alves D P, Rodrigues G B, Cardoso C R., Henriques da Silva D J. and Mizubuti E S G. 2011. Characterization of tomato accessions for resistance to early blight. Crop Breed Applied Biotechnol., pp 174-180.

Mayee, C.D., and Datar V V. 1986. Phytopatholometry Technical Bulletin-1. Marathwada Agricultural University Parbhani. pp. 46.

Narendrappa, N K N T and Nandini U. 2013. In vitro evaluation of botanicals, bioagents and fungicides against Alternaria solani causing early blight on tomato. Mysore Journal of 
Agricultural Sciences 47 (1): 180-183.

Nene, Y.L., and Thapliyal P N. 1982. Fungicides in Plant Disease Control. Oxford and IBH publishing Co. Pvt. Ltd. New Delhi. pp. 163.

Pandey, K.K., and Pandey P K. 2003. Survey and surveillance of vegetable growing area for prevalence of major diseases in this region. Vegetable Science 30: 128-134.

Rangaswamy, G., 1972. Diseases of crop plants in India. Prentice Hall of India Pvt. Ltd. New Delhi. pp. 520.

Rashmi, T., and Vishunavat K., 2012. Management of early blight (Alternaria solani) in tomato by integration of fungicides and cultural practices. International Journal of Plant Protection 5 (2): 201-206.

Shaukat, S.S., Z H. and Rao T A. 2013.
Antagonistic activity of cultural filtrates of five Trichoderma species against pathogenic fungus Alternaria solani. International Journal of Biology and Biotechnology 10 (4): 547-551.

Shekhawat, P.S.,and Prasada R. 1971. Antifungal properties of some plant extracts. Indian Phytopathology 24: 800-802.

Song, W., Ma X, Tan, H and Zhou J. 2011. Abscisic acid enhances resistance to Alternaria solani in tomato seedlings. Plant Physiology and Biochemistry 49: 693-700.

Vincent, JM., 1947. Distortion of fungal hyphae in presence of certain inhibitors. Nature 159, 850.

\section{How to cite this article:}

Salimso Chapei, Narola Pongener and Valenta Kangjam. 2019. Integrated Management of Early Blight of Tomato (Lycopersicon esculentum Mill.) caused by Alternaria solani (Ellis and Martin) Jones and Grout. Int.J.Curr.Microbiol.App.Sci. 8(05): 2428-2436.

doi: https://doi.org/10.20546/ijcmas.2019.805.287 